\title{
ALUMÍNIUMHABBAL MEREVÍTETT VÉKONYFALÚ CSÖVEK NYOMÁSSAL SZEMBENI VISELKEDÉSE
}

\author{
Garai Flórián - Hareancz Ferenc
}

\begin{abstract}
Absztrakt: Egyre gyorsuló és dinamikusan fejlődő világunkban a közlekedésnek kiemelkedő szerepe van. A közlekedés egyik folyamatosan fejlődő ágazata a közúti közlekedés. Az autóipar folyamatos fejlesztéseinek köszönhetően gyorsan fejlődő iparág. Azonban az egyre szigorodó környezetvédelmi szabályozások miatt a fő fejlesztések a jármüvek fogyasztásának és károsanyag-kibocsátásának csökkentésére irányulnak. A jármü össztömegének csökkentésével jelentősen csökkenthető a károsanyag-kibocsátás. Az össztömeg csökkentése a kötéstechnológiák fejlesztésével és új, korszerü anyagok felhasználásával viszonylag könnyen elérhető. Azonban az eszközölt változtatások nem csökkenthetik a jármü biztonsági besorolását. Ezek a követelmények előtérbe helyezik a belső merevítéssel ellátott elemek használatát, amelyek a megfelelő merevítő anyaggal ugyan azt a szilárdsági tényezőt tudják biztosítani, csak kisebb tömeggel. Egy ilyen korszerü, belső merevítésként használható anyag az alumíniumhab, amely ultrakönnyü, jó szilárdsági tulajdonságokkal és jó energiaelnyelő képességekkel rendelkezik. Az energiaelnyelö képessége leginkább az ütközések során keletkező energia elnyelésére, a fellépő erőhatások csökkentésére használható. Az ütközés következtében a karosszériaelemre ható erő és a váz által kifejtett ellenerő gyakorlatilag összenyomja az ott található biztonsági elemet. A cikkben az alumíniumhabbal merevített vékonyfalú csövek nyomással szembeni viselkedését vizsgáltuk, amelyekböl következtettünk az ütközéscsillapító elemként történő felhasználhatóságára.
\end{abstract}

\begin{abstract}
Traffic has an outstanding role in our accelerating and dynamically developing world. Road traffic is a constantly developing part of the traffic. Due to its continuous developments automotive industry is developing rapidly. However, due to increasingly stringent environmental regulations, major developments are aimed to reducing vehicle consumption and pollutant emission. Reducing the total weight of the vehicle can significantly reduce pollutant emission. Reducing total weight is relatively easy to achieve with the development of bonding technologies and the use of new advanced materials. However their changes must not reduce the safety factor. These requirements emphasize the use of internal reinforced elements, which can provide the same strength factor with less weight. Aluminium foam is a modern material which has good mechanical properties and energy-absorbing ability so it can be used as reinforcement material. Its energy-absorbing ability can be used to absorb energy generated by collisions and to reduce the forces that occur. The impact on the body part due to the impact and the force exerted by the chassis practically compresses the security element there. We investigated the compressive behavior of aluminium foam reinforced thin-walled tubes in this article to make conclusions about their usage as impact absorbers.
\end{abstract}

Kulcsszavak: környezetvédelem, súlycsökkentés, alumíniumhab, merevített csövek

Keywords: environmental protection, weight reduction, aluminium foam, reinforced tubes

\section{Bevezetés}

A fémhabok cellás, kis sủrüségủ anyagok, amelyek egyedi mechanikai, termikus, elektromos és akusztikai tulajdonságokkal rendelkeznek. Ezek a tulajdonságok nagy mértékben befolyásolják az alkalmazási területeiket. Elsősorban merev viselkedést mutatnak, de rendelkeznek bizonyos alakváltozási tulajdonságokkal is.

Az alumíniumhab alkalmazása nagy hatást gyakorolt a közúti- és légiközlekedésre, ahol az ütközési energia elnyelése, a rezgéscsillapítás, a zaj szint csökkentése és a súlycsökkentés is fontos tényező [1-3]. 
Az alumíniumhab autóiparban történő alkalmazása az utóbbi években egyre nagyobb érdeklődéssel bír, az erre irányuló fejlesztések száma növekszik. Az autókban található biztonsági rendszerek szolgálnak a legnagyobb lehetőséggel az alumíniumhabok felhasználására.

A személygépjármüvek biztonsági rendszereit két nagyobb csoportba sorolhatjuk, aktív és passzív biztonsági rendszerekre. Az aktív biztonsági rendszerek (sávtartó rendszerek, ütközés figyelő rendszerek) fő feladata a balesetmegelözés. A passzív biztonsági rendszerek feladata a baleset bekövetkezésekor az autó utasainak védelme, illetve kisebb koccanások esetén a keletkező károk minimalizálás. Az alumíniumhab potenciális felhasználási lehetősége a passzív biztonsági rendszerekben rejlik.

Az 1. ábrán aláhúzással jelölt elemek potenciális felhasználási területek az alumíniumhab alkalmazására. Ezekben az elemekben közös, hogy zárt profilok, amelyeket habbal feltöltve, kis súlynövekedés mellett feltételezéseink szerint nagyobb biztonsági faktort tudunk elérni vagy ugyan azt a biztonsági faktort kevesebb tömeggel el tudjuk érni.

\section{1. ábra: Biztonsági rendszerek}

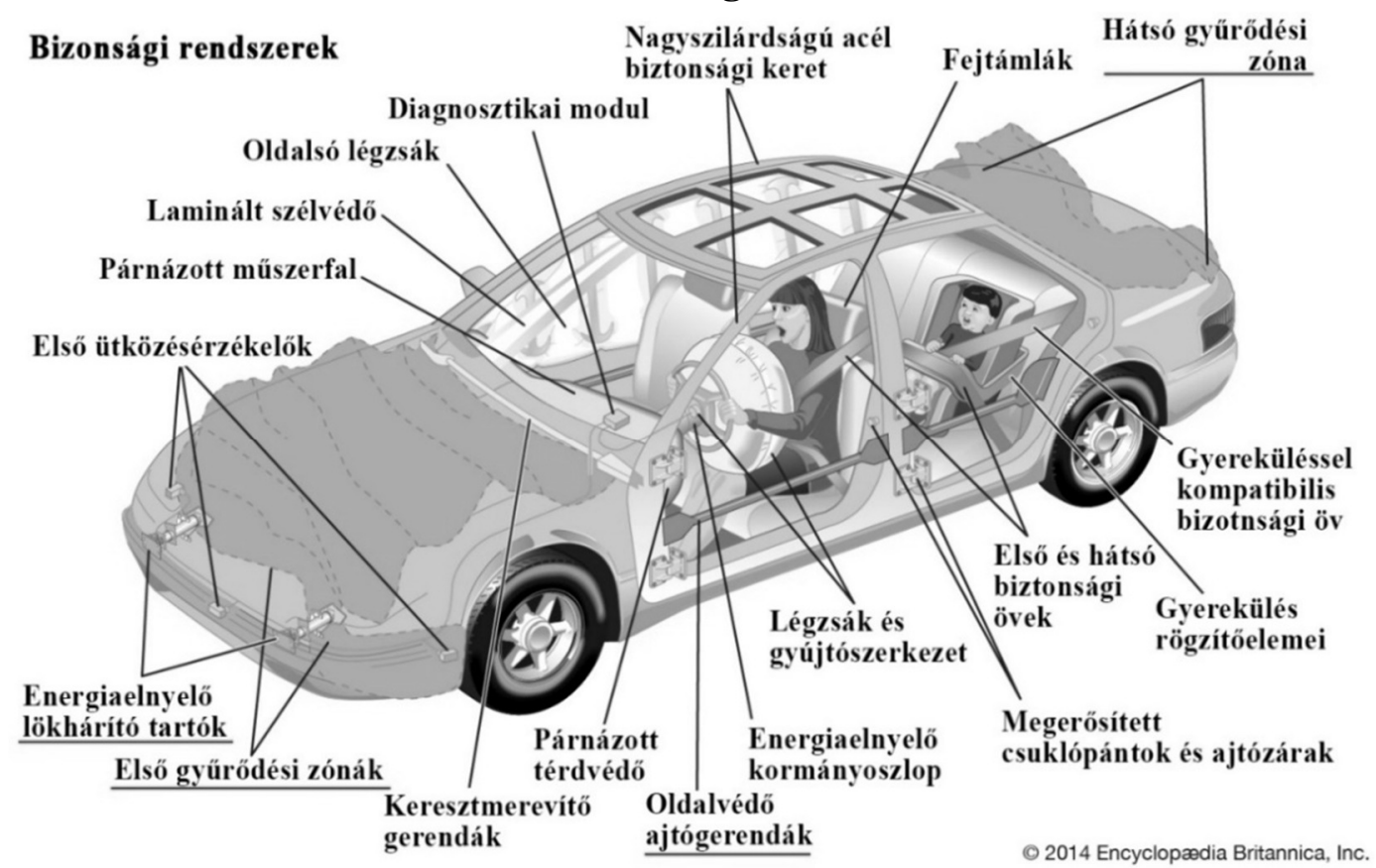

Orville C. Cromer, Christopher G. Foster, Ken W. Purdy, George C. Cromer: Automobile. https://www.britannica.com/technology/automobile

Az elülső és oldalsó gyürődési zóna egy az egyben az energiaelnyelésről és a deformációról szól, ezen zónák legfontosabb elemei közé tartoznak a törésdobozok. Ezek az elemek jellemzően vékonyfalú csövekből épülnek fel [4-6].

A cikk fö témája az alumíniumhabbal töltött vékonyfalú alumínium csövek nyomóvizsgálata és az üres csövekkel való összehasonlítása. 


\section{Alapanyagok, vizsgálati módszerek}

\subsection{Alapanyagok}

Alapanyagok:

- $\quad$ EN AW-6060-AlMgSi0,5 anyagminőségü; Ø25x0,5-ös méretü cső

- 0,5 g/cm3 sürüségü, EN 43100 (A1Si10Mg) anyagminőségü, 270x60x60-as méretü zárt cellás alumíniumhab tömb (2.ábra)

Használt gépek:

- Instron 4482 univerzális anyagvizsgáló berendezés

- E 4001000 egyetemes eszterga

- Keretes fürészgép

\section{2. ábra: Alumíniumhab tömb}

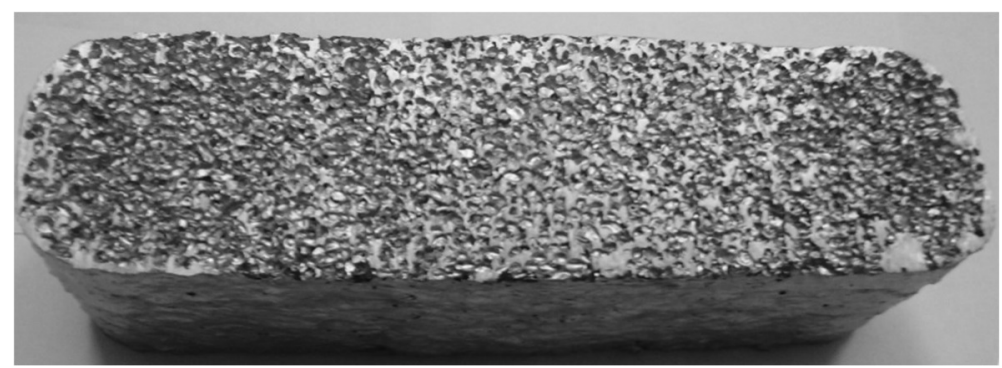

A szerzők saját szerkesztése (2018)

A csövek betöltésének első lépése az alumíniumhab rudak előállítása (3. ábra)

Az alumíniumhab megmunkálására, a rudak előállítására több módszert is teszteltünk, ezek közül az esztergálás bizonyult a legjobbnak. Az esztergálással elöállított habrudak között is vannak eltérések, amelyek leginkább az anyag inhomogenitásából, valamint a habok központosításának és megtámasztásának nehézségeiből származnak.

\section{3.ábra: Alumíniumhab rúd}

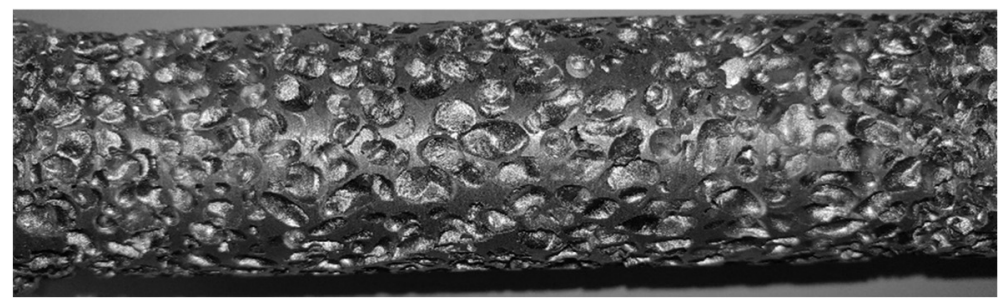

A szerzők saját szerkesztése (2018)

Az alumíniumhab rudak csőbe töltése préseléssel történt.

\subsection{Vizsgálati módszer}

A vizsgálati módszer a felhasználásra szánt elem igénybevételének megfelelően nyomóvizsgálat volt. A valós igénybevétel általában dinamikus, ritkán statikus. Azonban Isabel Duarte és társainak publikációja alapján nincs számottevő különbség 
az általunk vizsgálni kívánt paraméterek esetében a statikus és a dinamikus igénybevételek között [7]. Ezért statikus igénybevételnek tettük ki a próbatesteket, az 1. táblázat tartalmazza a vizsgálati paramétereket. A nyomóvizsgálat elsődleges célja olyan rideg anyagok terhelhetőségének a mérésére szolgál, melyek a szakításnál a húzófeszültségek hatására sokkal kisebb terhelésnél törnek, mint nyomóterhelés esetén. Az alumínium hab is rideg anyag, azonban itt a szakító próbatest kialakítása is komoly erő-feszítések árán mehetne végbe, míg a habosított tömbök nyomása könnyen és gyorsan elvégezhető. A kihajlás veszélyét szem elött tartva a magasság/átmérö viszonyt 2,5-ös érték alatt tartottuk.

\begin{tabular}{|c|c|c|c|c|}
\hline \multicolumn{5}{|c|}{ 1.táblázat: Vizsgálati paraméterek } \\
\hline $\begin{array}{l}\text { Keresztfej } \\
\text { sebessége } \\
\text { [mm/min] }\end{array}$ & $\begin{array}{c}\text { Kiinduló } \\
\text { magasság } \\
\text { [mm] }\end{array}$ & $\begin{array}{c}\text { Nyomás } \\
\text { utáni } \\
\text { magasság } \\
\text { [mm] }\end{array}$ & $\begin{array}{c}\text { h/D } \\
\text { viszony }\end{array}$ & $\begin{array}{c}\text { Zömítési } \\
\text { arány } \\
{[\%]}\end{array}$ \\
\hline \multirow{5}{*}{25} & 25 & 12,5 & 1 & 50 \\
\hline & 30 & 15 & 1,2 & 50 \\
\hline & 40 & 20 & 1,6 & 50 \\
\hline & 50 & 25 & 2 & 50 \\
\hline & 60 & 30 & 2,4 & 50 \\
\hline
\end{tabular}

Forrás: A szerzők saját szerkesztése (2019)

A vizsgáló berendezés az Instron 4482 univerzális anyagvizsgáló berendezés volt, amelyre rögzítettük a nyomófejet és az ellendarabot (4. ábra). A nyomásközéppont és a próbatestek egytengelyüségére ügyeltünk.

\section{4. ábra: Vizsgálati elrendezés}

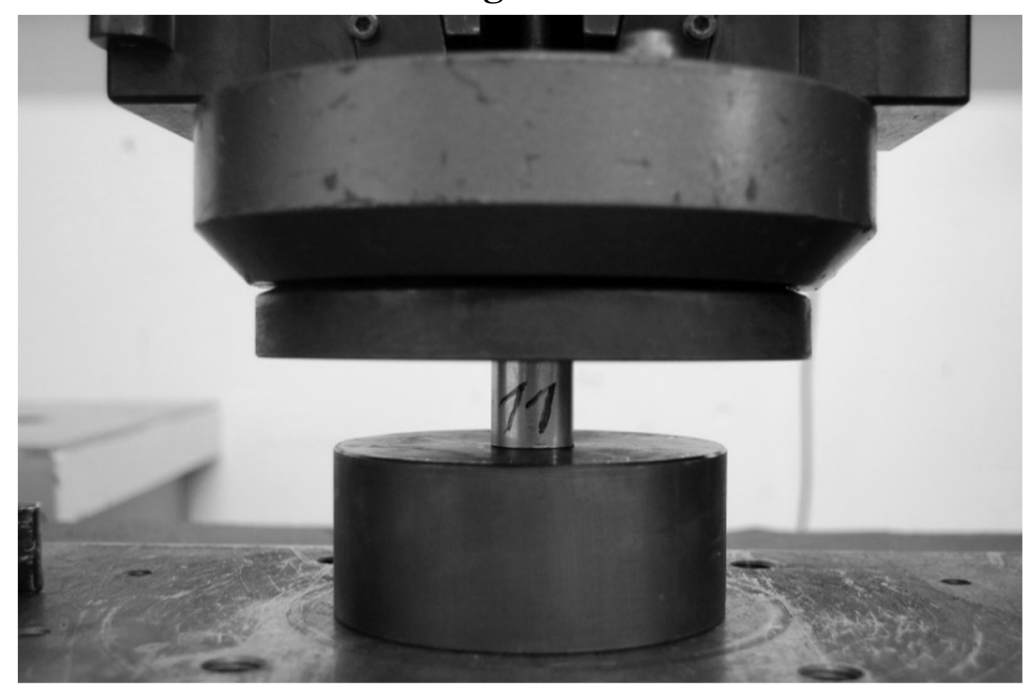

Forrás: A szerzők saját szerkesztése (2019) 


\section{Eredmények, kiértékelés}

A vizsgálat során a berendezés mérte az erőt és az elmozdulást. A próbatest által elnyelt energia megegyezik a szerszám által rajta végzett munkával. A súrlódást elhanyagoltuk. Az elnyelt energiát integrálással számoltuk.

$\mathrm{Az}$ 5. és 6. ábrán a legkisebb és legnagyobb $\mathrm{h} / \mathrm{D}$ viszonyú próbatestek eröelmozdulás diagramjai láthatóak.

\section{5. ábra: 1-es $\mathbf{h} / \mathbf{D}$ viszonyú próbatest erő-elmozdulás diagramja}

\section{5 mm magasságú próbatest}

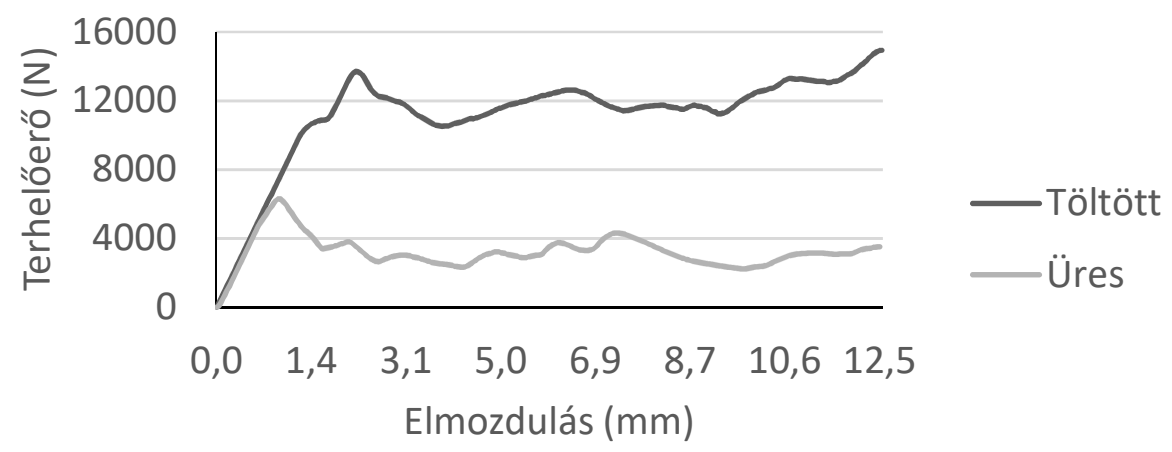

\section{6. ábra: 2,4-es h/D viszonyú próbatest erő-elmozdulás diagramja}

\section{0 mm magasságú próbatest}

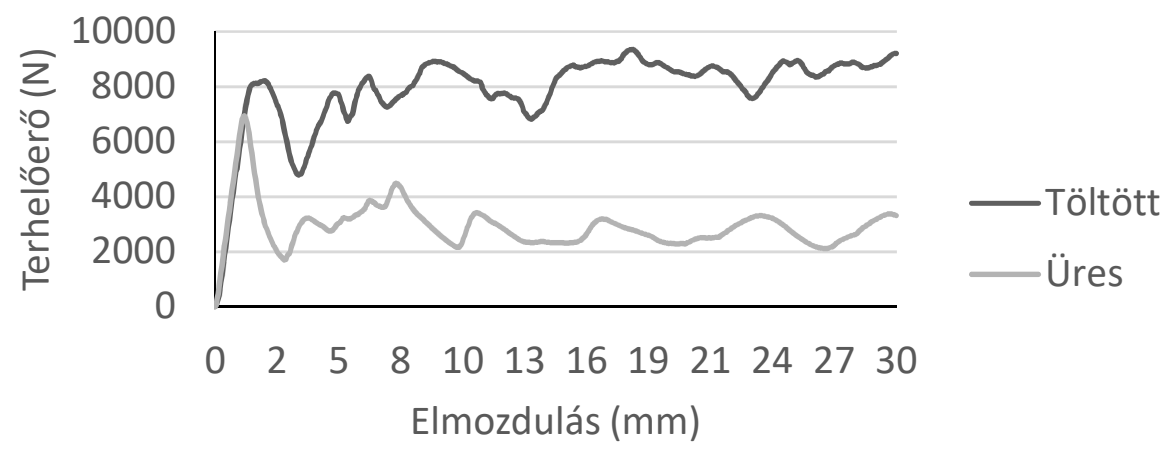

A bemutatott erö-elmozdulás diagramokból leszürhető a tendencia, miszerint az üres csövek által elviselt terhelőerő az elmozdulás növekedésével egy maximális erőérték elérése után egy kisebb erőérték körül lévő tartományban stagnál. Ezzel szemben az alumíniumhabbal töltött csövek az elmozdulás növekedésével erőcsúcsokat produkálnak. Ez által arra következtethetünk, hogy a töltött csövek dinamikus igénybevételek hatására kevésbé érzékenyek. Ez teljes mértékben összhangban van a már korábbiakban említett, Isabel Duarte és társai által publikált megfigyelésekkel [7]. 
A vizsgálatok 50\%-os zömítési aránnyal történtek, a diagramokon megfigyelhető, hogy a beállított elmozdulás értéket elérve a terhelőerő emelkedő tendenciát mutatott. Ebből az következik, hogy ha folytatódott volna a vizsgálat nagyobb zömítési arányig, a töltött csövekre ható terhelőerő még nagyobb értékeket vett volna föl.

Ezt a jövőben további vizsgálatokkal igazolni szeretnénk.

\section{7. ábra: Próbatestek energiaelnyelése}

\section{Energiafelvétel}

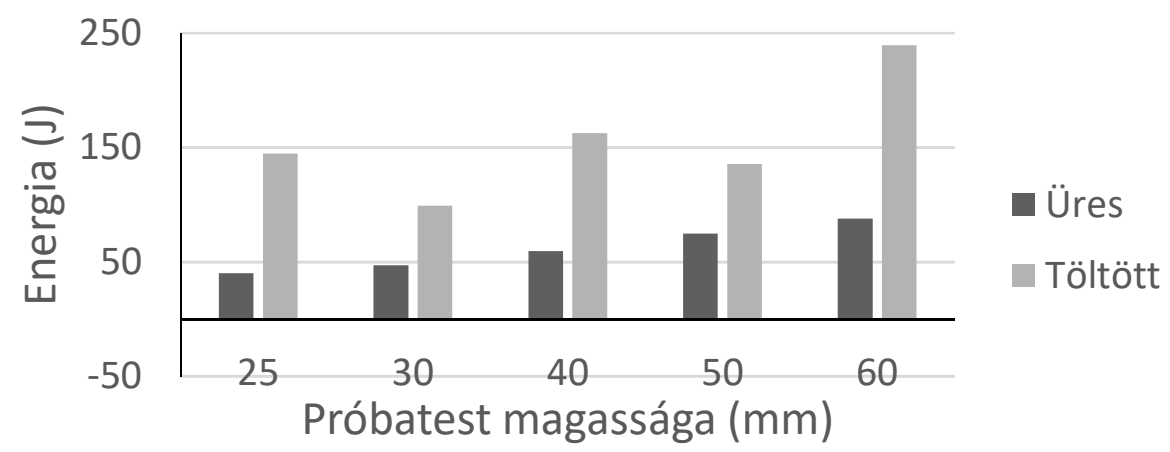

A kiértékelés egyik legfontosabb szempontja maga az energiafelvétel (7. ábra). A töltött csövek energiafelvétele $270 \%$-a az üres csövek energiafelvételének. A habok inhomogenitása és a préseléssel történő betöltés okozta deformáció miatt a töltött csövek esetében nem figyelhető meg egy monoton növekvő tendencia. Ezt az egyéb töltési eljárások (pl.: csőben való habosítás) kiküszöbölik és egy monoton növekvő tendenciát mutatnak [7]

\section{8. ábra: Próbatestek tömegei}

\section{Össztömeg}

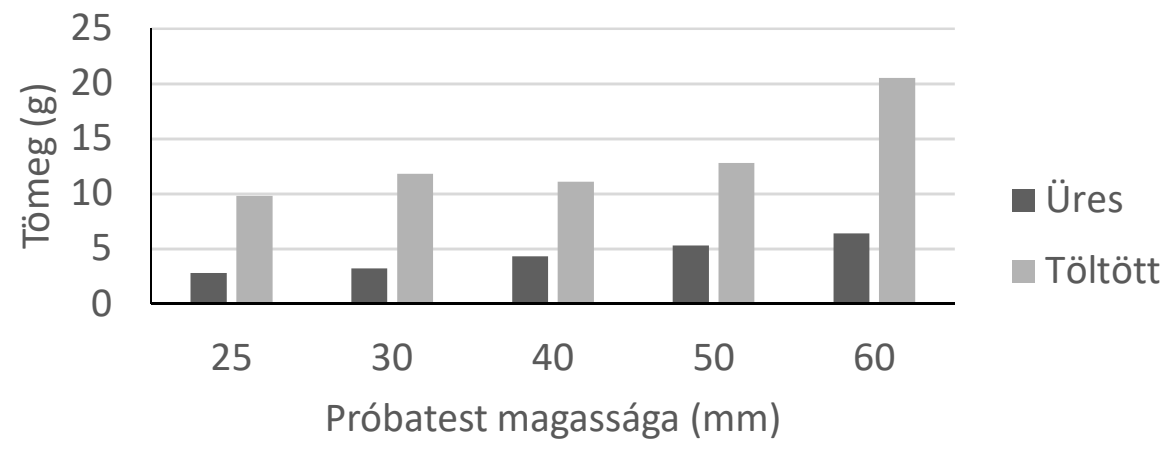

A másik alapvető szempont a tömegnövekedés (8. ábra). A töltött csövek tömege átlagosan 290\%-ára nőtt a vizsgálatok során. Ahhoz, hogy üres csővel megegyezö energiafelvételt érjünk el, mint a töltött csövekkel, 4-5 mm-es 
falvastagságú csövek szükségesek. Tömegben ez nem sokkal tér el a töltött csövektöl.

Ahhoz, hogy a töltött csöveket magabiztosan használni tudjuk elöször a méretezésüket kell megoldanunk. Az energiaelnyelés a gépjármüvek ezen elemeinél szinte mindig nyomó igénybevétel hatására, deformáció útján fog történni. A maximális deformáció értékét ismerni fogjuk, ezért célszerü lenne egy olyan viszonyszám megállapítása, amely az adott sürüségü alumíniumhab egységnyi alakváltozás értékéhez társított szükséges energiabevitelt adja meg. Ezt nevezzük fajlagos energiaszükségletnek. Ennek ismeretében a várható alakváltozás értékével megszorozva képet kapunk az elem várható energiafelvételéről.

Az alakváltozás $(\varphi)$ számítása az alábbi képlettel történik:

ahol:

$$
\varphi=\ln \left(\frac{h}{H}\right) \quad\left[\frac{m m}{m m}\right]
$$

$\mathrm{h}=$ a nyomás elötti próbatest magassága

$\mathrm{H}=$ próbatest vizsgálat utáni magassága

A zömítési arány mindegyik magasság esetében $50 \%$, ezért a képletbe (1) bármely vizsgálati magasságot behelyettesítve 0,69-es értéket kapunk.

A képlékenyalakítási szempontok alapján a valódi alakváltozást célszerü meghatározni. Az adott anyagú és méretű elem folyásgörbéjét mérések segítségével meghatározhatjuk. Az alakítási szilárdság ismeretében az adott alumínium habbal töltött cső méretezhető, energiafelvétele és tömege alapján optimalizálhatóvá válik.

\section{9. ábra: Egységnyi alakváltozás energiaszükséglete}

Fajlagos energiaszükséglet

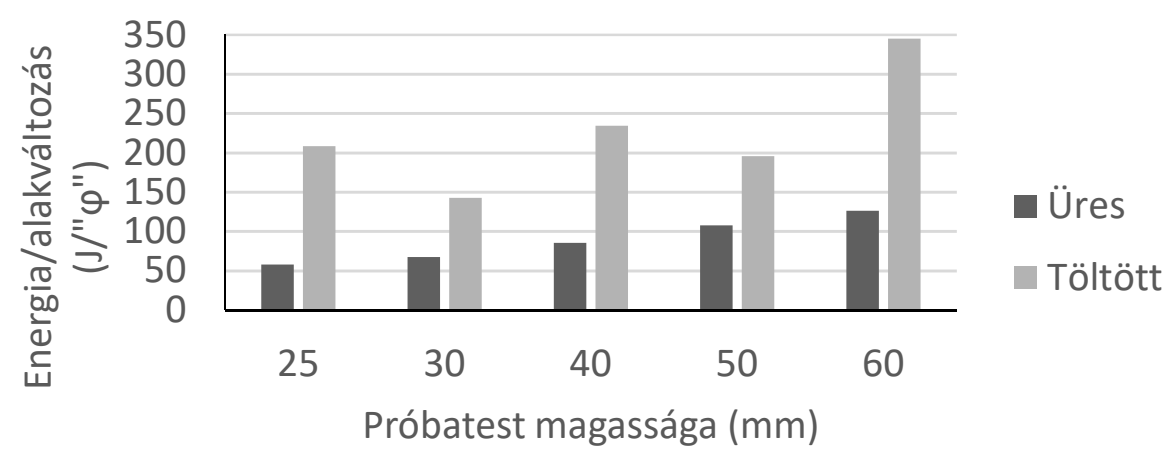

A 9. ábrán láthatjuk a kapott értékek diagramját. Kellő mennyiségü mérés elvégzése után az átlagolt érték fogja leírni a használt sủrüségủ alumíniumhab fajlagos energiaszükségletét.

Az utolsó vizsgálati szempont az elem energiasürüsége. Ennek lényege, hogy az elem $1 \mathrm{~cm}^{3}$-nyi térfogata mekkora energiafelvételre képes. 
Az energiasűrủség a következő összefüggésből számolható:

ahol:

$$
\text { Energiasűrűség }=\frac{E}{V}=\frac{\int_{0}^{\frac{h}{2}} F d s}{\frac{d^{2} * \pi}{4} * h} \quad\left[\frac{J}{\mathrm{~cm}^{3}}\right]
$$

$\mathrm{E}=$ elnyelt energia

$\mathrm{V}=$ próbatest által elfoglalt térfogat

$\mathrm{F}=$ terhelés

$\mathrm{s}=$ elmozdulás

$\mathrm{d}=$ próbatest külső átmérője

$\mathrm{h}=$ próbatest magassága

10. ábra: Energiasürüség az elfoglalt térfogat függvényében

Energiasűrűség

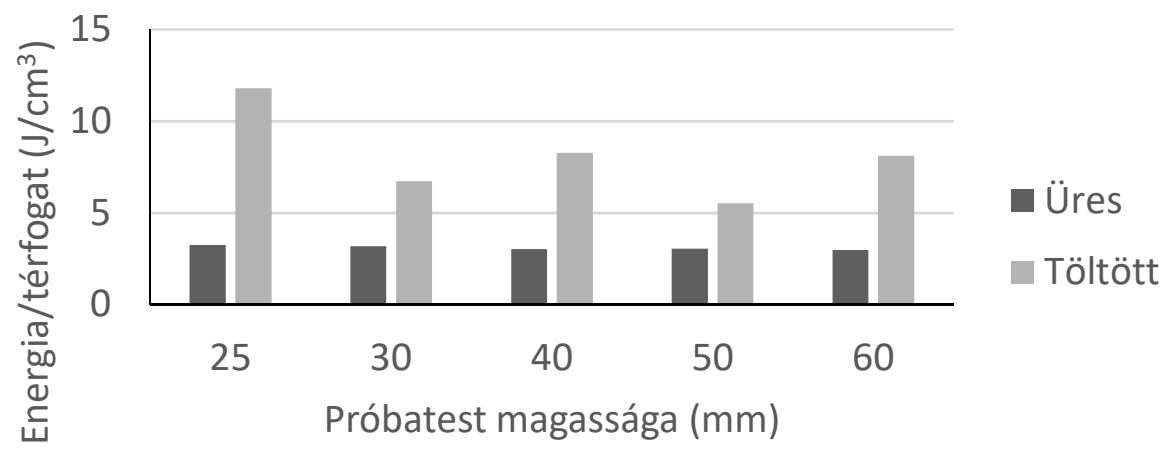

A 10. ábra alapján a töltött csövek jobb eredményt értek el ebben az összevetésben is, mint az üres csövek.

\section{Következtetések, összegzés}

Az eddig leírtak alapján megállapítható, hogy az alumíniumhabbal töltött cső energiafelvétele nagyobb, mint az üres csövek esetén. A vizsgálataink során a tömegnövekedés ezt ellensúlyozta, de a betöltési technológia változtatásával ez jelentős mértékben csökkenthető.

Ezek alapján két féle értelemzésben történhet az alumíniumhabbal töltött cső energiaelnyelő elemekben történő használata. Az egyik, hogy a már eleve a gépjármüben használt elemet töltjük fel habbal, amely a megfelelő töltési technológiával és optimalizálásával minimális tömegnövekedéssel nagyobb energiaelnyelést és szilárdságot fog biztosítani, mint az eddigi elem. A másik lehetőség a kisebb méretü, de töltött cső alkalmazása, amely kevesebb tömeg mellett fogja biztosítani ugyan azt a mennyiségü energiafelvételt. A kisebb méretủ elemek 
használata lehetőséget nyújt a váz áttervezésére, a kialakítás módosítására (pl.: nagyobb utastér, csomagtartó).

Mindkét alkalmazás hozzájárul a biztonsági faktor fenntartásához, ezáltal használható autóipari energialenyelő elemként.

\section{Köszönetnyilvánítás}

A projekt az Európai Unió támogatásával, az Európai Szociális Alap társfinanszírozásával valósul meg. EFOP-3.6.1-16-2016-00014

Szeretnénk köszönetet mondani az Aluinvent Zrt.-nek az alumíniumhab alapanyagok biztosításáért és a habokkal kapcsolatos tapasztalataik megosztásáért.

\section{Irodalomjegyzék}

1. John Banhart: Manufacturing Routes for Metallic Foams, JOM: the journal of the Minerals, Metals \& Ma-terials Society, 2012 52(12):22-27

2. D. K. Rajak, N.N. Mahajan, E. Linul: Crashworthiness performance and microstructural characteristics of foam-filled thin-walled tubes under diverse strain rate, Journal of Alloys and Compounds 775 (2019), pp. 675-689

3. M. F. Ashby, A. G. Evans, N. A. Fleck, L. J. Gibson, J. W. Hutchinson, H. N. G. Wadley: Metal Foams: A Design Guide

Elektronikus forrás: http://ceb.ac.in/knowledge-center/E-BOOKS/Metal\%20Foams\%20\%20A\%20Design\%20Guide\%20-\%20M.F.\%20Ashby.pdf (Megtekintés: 2018.07.25.)

4. T. Dennis Claar, Chin-Jye Vu, lan Hall, John Banhart, Joachim Baumeister, Wolfgang Seeliger: Ultra-lightweight Aluminum Foam Materials for Automotive Applications., SAE Technical Papers 36(6):61, 2000 (Megtekintés: 2018.08.01.)

5. Ed Grabianowski: How Crumple Zones Work.

Elektronikus forrás: https://auto.howstuffworks.com/car-driving-safety/safety-regulatorydevices/crumple-zone.htm. (Megtekintés: 2018.08.04.)

6. Antonio Fuganti, Lorenzo Lorenzi, Arve Gr nsund Hanssen, Magnus Langseth: Aluminium foam for automotive applications, Advanced Engineering Materials 2(4):200 - 204. April 2000 (Megtekintés: 2018.08.04.)

7. Isabel Duarte, Matej Vesenjak, Lovre Krstulovic, Opara, Zoran Ren: Static and dynamic axial crush performance of in-situ foam-filled tubes, Composite Structures 124 (2015) 128139 (Megtekintés: 2018.08.15.) 